\section{Specificity-Enhanced Hot-Start PCR: Addition of Double-Stranded DNA Fragments Adapted to the Annealing Temperature}

BioTechniques 28:278-282 (February 2000)

\begin{abstract}
A new method to produce hot-start conditions in PCR is described. Short doublestranded DNA fragments were found to inhibit the activity of DNA polymerases from Thermus aquaticus and Thermus flavus. This inhibition is not sequence specific, but exclusively dependent on the melting temperature of the fragments as shown by its correlation to their melting curves as measured. This property is exploited by adding fragments of the appropriate length to the PCR mixture during the reaction setup and thereby preventing the DNA polymerases from extending primers annealed nonspecifically at lower than the optimal temperature. By amplifying ten copies of phage $\lambda$ DNA in the presence of $2 \mu \mathrm{g}$ of nonspecific DNA, it is shown for three different primer pairs how the melting temperatures of the doublestranded DNA fragments have to be adapted to the cycle profiles to obtain predominantly specific products in the $0.5 \mu \mathrm{g}$ range.
\end{abstract}

\section{INTRODUCTION}

Especially in the amplification of low copy number targets in a background of nonspecific nucleic acids, hot-start PCR has been shown to eliminate undesirable amplification products. These products result from the extension of nonspecifically annealed primers that occurs during the reaction setup at temperatures below the optimum for specific annealing $(2,4)$.

Hot-start PCR has been implemented so far by mechanically separating a reagent (7), by blocking the DNA polymerase with an antibody (8) or by using AmpliTaq Gold ${ }^{\circledR}$ (PE Biosystems, Foster City, CA, USA), a modified form of AmpliTaq DNA polymerase that is inactive at room temperature (1). In two recent reports, single-stranded DNA aptamers (oligonucleotides selected by an in vitro selection procedure) were shown to inhibit the activity of various DNA polymerases. At temperatures below $40^{\circ} \mathrm{C}$, the aptamers inhibited the enzyme, while at temperatures above $40^{\circ} \mathrm{C}$, they became inactive as inhibitors. This has been shown to be useful in amplification of low copy number targets in a background of nonspecific DNA $(3,9)$.

In this report, we first provide evidence that from various DNA polymerases tested, the widely used Taq and $T f l$ DNA polymerases are inhibited by short double-stranded DNA fragments. Second, the presence of these fragments in PCR mixtures is also appropriate to produce hot-start conditions. In contrast to aptamers, the inhibition depends only on the melting temperature of the fragments, but not on their sequence. Specificity-enhanced hot-start PCR is especially useful because the temperature at which the activity of the polymerase is released is adaptable to the conditions required using the melting temperature of the DNA fragments. Moreover, the protection against mispriming at a lower than optimal temperature persists throughout the PCR due to the thermal reversibility of the inhibition.

\section{MATERIALS AND METHODS}

\section{DNA Polymerases}

Used in these experiments were: AmpliTaq DNA polymerase, Taq DNA polymerase (Roche Molecular Biochemicals, Mannheim, Germany), Biotherm $^{\mathrm{TM}}$ Taq DNA polymerase (genXpress, Vienna, Austria), Tfl DNA polymerase (Epicenter Technologies, Madison, WI, USA), Tth DNA polymerase (Amersham Pharmacia Biotech, Uppsala, Sweden), Vent DNA polymerase (New England Biolabs, Beverly, MA, USA) and Pwo DNA polymerase (Roche Molecular Biochemicals).

\section{DNA Samples}

$\lambda$ DNA was purchased from Roche Molecular Biochemicals. The oligonucleotide primers were selected using OLIGO $5.0^{\circledR}$ primer analysis software
(Medprobe A.S., St. Haunshaugen, Norway) and were synthesized either by MWG (Ebersberg, Germany) or by genXpress. The $\lambda$ DNA correspondence of the primer pairs were: $(i)$ forward 20393-20417 and reverse 21355-21335; (ii) forward 2039320417 and reverse 22 120-22 096; (iii) forward 10443-10467 and reverse 11413-11394.

The sequences of the double-stranded DNA fragments used have been designed arbitrarily, starting from a predetermined length and modified only to the extent necessary to prevent hairpins and dimer formations (according to OLIGO), but not selected in any other way. The melting temperatures of the primers and double-stranded DNA fragments were calculated from the following equation: $69.3+0.41(\mathrm{G}+\mathrm{C}) \%$ $-650 / \mathrm{L}$ where $\mathrm{L}$ is the oligonucleotide length $\left(\mathrm{T}_{\mathrm{m}}\right.$ calc. $)$. Furthermore, the melting temperatures of the doublestranded DNA fragments were deduced from their melting curves $\left(\mathrm{T}_{\mathrm{m}}\right.$ meas. $)$ that were measured in the PCR conditions. Table 1 summarizes the sequences of the primer pairs used.

\section{Hairpin Extension Assay}

For testing the temperature dependent inhibition of Taq and Tfl DNA polymerase by the presence of various double-stranded DNA fragments, a hairpin extension assay was performed as described previously (9). Modifications of the original protocol are summarized in the Figure 1 legend.

\section{Amplification Conditions}

As a test system for low copy number target amplification, we amplified target sequences of $1 \mathrm{~kb}$ or $1.7 \mathrm{~kb}$ length, respectively, starting with approximately 10 copies of a phage $\lambda$ genome in the presence of $2 \mu \mathrm{g}$ of nonspecific DNA consisting of $1 \mu \mathrm{g}$ of calf thymus DNA and $1 \mu \mathrm{g}$ of Escherichia coli DNA (if not indicated otherwise).

The $50 \mu \mathrm{L}$ standard reaction mixtures contained the following components: $0.4 \mu \mathrm{M}$ of each primer, $0.2 \mathrm{mM}$ of each dNTP (Amersham Pharmacia Biotech), $1.5 \mathrm{mM} \mathrm{MgCl} 2\left(\mathrm{MgSO}_{4}\right.$ for Vent and Pwo DNA polymerase), 10 copies of $\lambda$ DNA, 0 (control) or $2 \mu \mathrm{g}$ of 
Table 1. Primers and Double-Stranded DNA Fragments Used

\begin{tabular}{|c|c|c|c|}
\hline Primer & Sequence $\left(5^{\prime}\right.$ to $\left.3^{\prime}\right)$ & $T_{m}$ calc. & $T_{m}$ meas \\
\hline \multirow{2}{*}{$\begin{array}{l}\text { 1: forward } \\
\text { reverse }\end{array}$} & ATCAGAAACGAACGCATCATCAAGT & 59.7 & \\
\hline & GCCTCGCATATCAGGAAGCAC & 61.8 & \\
\hline \multirow{2}{*}{$\begin{array}{l}\text { 2: } \\
\text { reverward }\end{array}$} & ATCAGAAACGAACGCATCATCAAGT & 59.7 & \\
\hline & AAACAGCCACAAAGCCAGCCGGAAT & 64.6 & \\
\hline \multirow{2}{*}{$\begin{array}{l}\text { 3: } \text { forward } \\
\text { reverse }\end{array}$} & GGAATGAAGTTATCCCCGCTTCCCC & 66.3 & \\
\hline & CCAGGTCTCCAGCGTGCCCA & 65.5 & \\
\hline \multicolumn{4}{|c|}{ + Strand of double-stranded DNA fragment: } \\
\hline A & AGCGGATAACAATATCA & 45.5 & 55.5 \\
\hline B & ATTAACССТСАСТAAAG & 45.5 & 53.5 \\
\hline C & AGTCAGTAGTAACCAG & 46.6 & 56.0 \\
\hline $\mathrm{D}$ & CACCACAAACAGAAAC & 46.6 & 56.2 \\
\hline$E$ & AGCGGATAACAATATCACA & 50.2 & 60.0 \\
\hline$E-1$ & ACGGATAACAATATCACA & 46.9 & 56.5 \\
\hline E-2 & CGGATAACAATATCACA & 45.5 & 52.5 \\
\hline $\mathrm{F}$ & CACCACAAACAGAAACAGAAC & 55.9 & 63.0 \\
\hline G & CGGGAATTCTGGCTCTGC & 58.2 & 69.5 \\
\hline
\end{tabular}

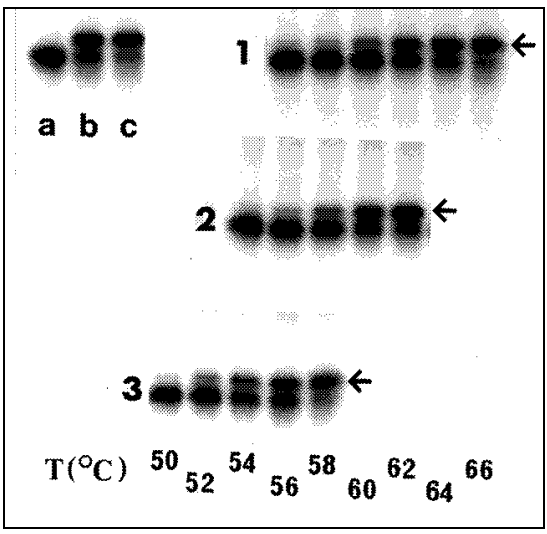

Figure 1. Effect of temperature on the inhibition of $\operatorname{Taq}$ DNA polymerase by the presence of double stranded DNA fragments E, E-1 and E2. Hairpin extension assay in $50 \mu \mathrm{L}$ reaction volume with $0.25 \mathrm{U}$ of $T a q$ DNA polymerase and 0.5 pmol of end-labeled DNA hairpin fragment was carried out either in the absence (lane $\mathrm{b}$ at $50^{\circ} \mathrm{C}$ and lane $\mathrm{c}$ at $60^{\circ} \mathrm{C}$ ) or in the presence of $1 \mu \mathrm{M}$ double-stranded DNA fragment E (panel 1), E-1 (panel 2) and E-2 (panel 3) at indicated temperatures for $10 \mathrm{~min}$. Lane a: control, hairpin fragment incubated without polymerase. The extension products were resolved on $15 \%$ polyacrylamide (wt/vol) gels under denaturing conditions ( $7 \mathrm{M}$ urea). Arrows in each panel of the figure show the position of the extended hairpin. nonspecific DNA and $1 \mathrm{U}$ of DNA polymerase using the standard buffer as supplied with the respective enzyme. Double-stranded DNA fragments were prepared by annealing equimolar amounts of their single strands in $1 \times$ standard buffer by slowly cooling to room temperature after heating to $75^{\circ} \mathrm{C}$ for $5 \mathrm{~min}$. One unit of DNA polymerase and $0.6 \mu \mathrm{g}$ of double-stranded DNA fragments, if not indicated otherwise, were either combined in a total volume of $5 \mu \mathrm{L} 1 \times$ standard buffer before addition or added separately to the reaction mixture. In any case, the fragments should encounter the DNA polymerase before the template and primers are added. All reactions were set up at room temperature and finally overlaid with $35 \mu \mathrm{L}$ of light mineral oil (Sigma, Vienna, Austria).

The PCRs were carried out in 0.2 $\mathrm{mL}$ reaction tubes using a 96-well Robocycler ${ }^{\circledR}$, both from Stratagene (La Jolla, CA, USA). Cycling conditions were as follows: $2 \mathrm{~min}$ at $93^{\circ} \mathrm{C}$, followed by 45 cycles consisting of $50 \mathrm{~s}$ at 


\section{Short Technical Reports}

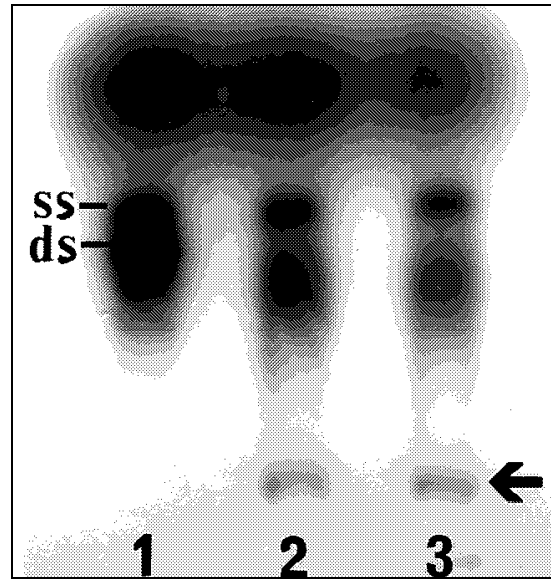

Figure 2. Binding of double-stranded DNA fragment G to $T a q$ and $T f l$ DNA polymerase. The mobility shift assay was performed as follows: $5 \mathrm{U}$ of the respective enzymes were mixed with $2.5 \mathrm{pmol}$ of $5^{\prime}$-end-labeled DNA fragment G in a total volume of $10 \mu \mathrm{L} 1 \times$ reaction buffer, incubated for $10 \mathrm{~min}$ at room temperature and subjected to electrophoresis. The labels ss and ds indicate the positions of single- and double-stranded DNA in the control. Lane 1, control (no polymerase added); lane 2, Taq DNA polymerase; lane 3, Tfl DNA polymerase. The electrophoretic separation was performed using 3\% (wt/vol) MetaphoreAgarose $^{\circledR}$ (FMC). The arrow shows the position of the retarded double-stranded fragment. $60^{\circ} \mathrm{C}, 1$ min (length of target sequence: $1 \mathrm{~kb}), 1 \mathrm{~min} 30 \mathrm{~s}(1.7 \mathrm{~kb})$ at $68^{\circ} \mathrm{C}$ and 1 min at $93^{\circ} \mathrm{C}$; and 1 final extension cycle of $50 \mathrm{~s}$ at $60^{\circ} \mathrm{C}, 2 \mathrm{~min}$ or $4 \mathrm{~min}$, respectively, at $68^{\circ} \mathrm{C}$, except Figure 5, Panel A (see legend). The PCR products were analyzed by $1 \%$ agarose gel electrophoresis and ethidium bromide staining. As the molecular weight standard, we used the $1 \mathrm{~kb}$ plus ladder from Life Technologies (Vienna, Austria).

\section{RESULTS AND DISCUSSION}

Figure 1 shows the representative results of the hairpin extension assays. Three double-stranded DNA fragments of the same sequence but of different length were compared for their ability to inhibit the activity of Taq DNA polymerase at different temperatures. The fragments used were shortened by one (Figure 1, panel 2) and by two nucleotides (Figure 1, panel 3) compared to fragment E (Figure 1, panel 1, sequences are summarized in Table 1). The incubation at temperatures lower than the fragment melting temperature as measured resulted in a complete in-

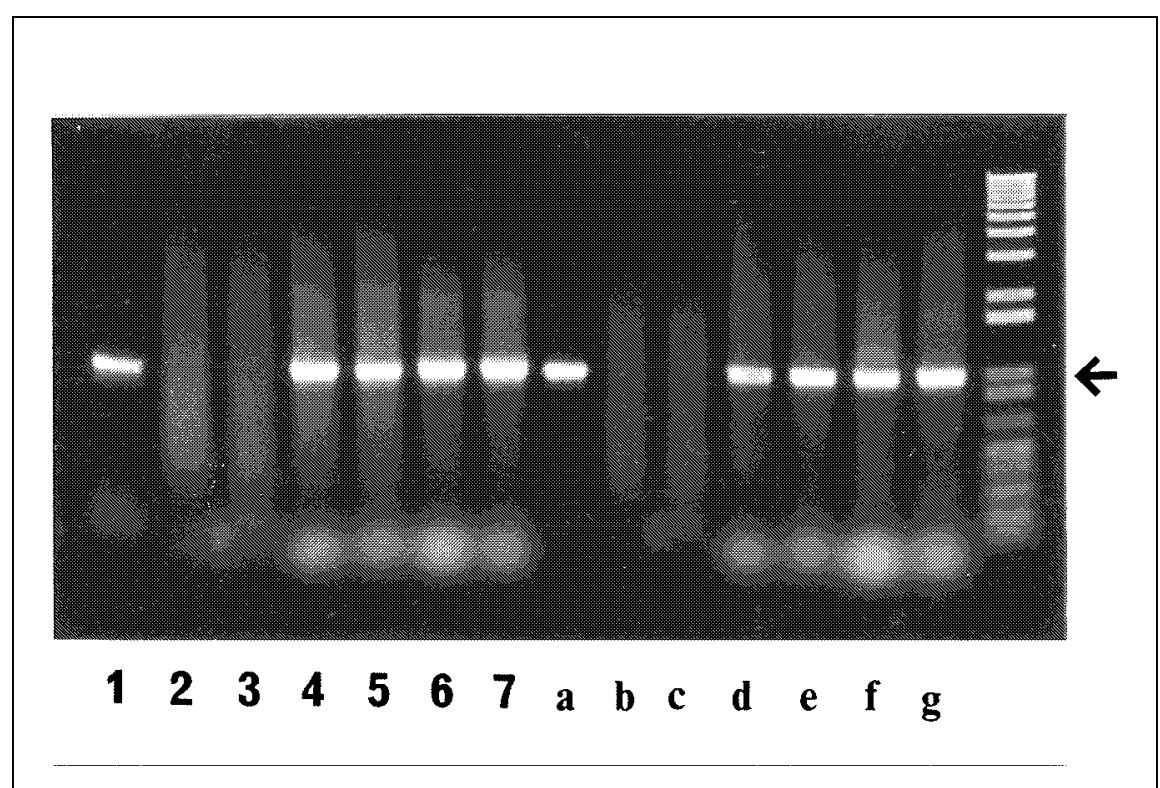

Figure 3. Comparing the effect of double-stranded DNA fragments of different sequences on the ability of $T a q$ and $T f l$ DNA polymerase to amplify low copy targets. PCRs using primer pair 1 contained 10 copies of $\lambda$ DNA in the presence of $2 \mu \mathrm{g}$ of calf thymus DNA (lanes 2-7 and b-g). AmpliTaq DNA polymerase (lanes 1-7): lane 1, control (no calf thymus DNA, no DNA fragments); lane 2, control (no DNA fragments); lane 3, + strand of DNA fragment A; lanes 4, 5, 6 and 7, double-stranded DNA fragment A, B, C and D, respectively; Tfl DNA polymerase (lanes a-g): corresponding to lanes 1-7. See Table 1 for the sequences of primers and DNA fragments. Reaction mixtures and parameters were as described in Materials and Methods. hibition of the DNA polymerase. Its activity was fully retained at $66^{\circ} \mathrm{C}$ (Panel 1), $62^{\circ} \mathrm{C}$ (Panel 2) and $58^{\circ} \mathrm{C}$ (Panel 3) as can be seen from the extension of the $3^{\prime}$ recessed ends of the hairpins compared to the control. These results indicate the inhibition to be strictly related to the measured melting temperatures $\left(\mathrm{T}_{\mathrm{m} \text { meas. }}\right.$ plus an additional $\left.6^{\circ} \mathrm{C}\right)$, but not to melting temperature values estimated by calculation that differed between $7^{\circ} \mathrm{C}$ and $10^{\circ} \mathrm{C}$ (Table 1). Hairpin extension studies using $T f l$ DNA polymerase including DNA fragments A-G lead to exactly the same conclusions as above and therefore are not shown.

The selective binding of Taq and Tfl DNA polymerase to double-stranded DNA fragment $\mathrm{G}$ is illustrated in Figure 2. Only the migration of the doublestranded fragment is retarded, while the mobility of single-stranded DNA that resulted from incomplete renaturation of the complementary strands remains unchanged.

Figure 3 summarizes the amplification results obtained by using Taq (lanes 1-7) and Tfl DNA polymerase (lanes

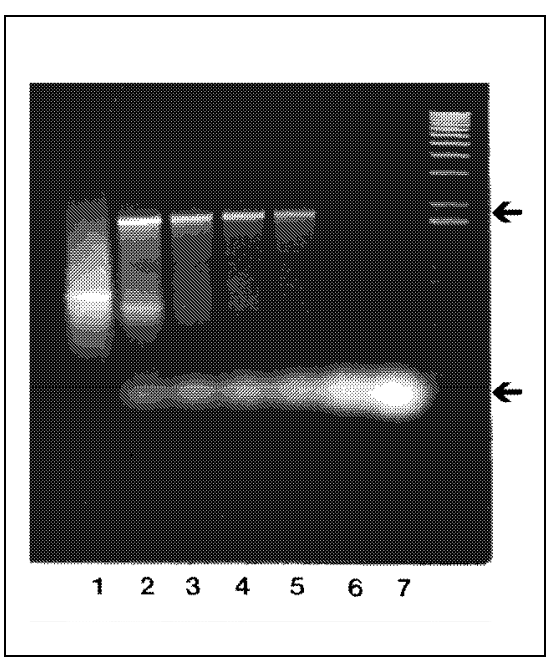

Figure 4. The effect of different amounts of double-stranded DNA fragment $A$ on product yield and reaction specificity. PCRs using primer pair 2 contained 10 copies of $\lambda$ DNA in the presence of $2 \mu \mathrm{g}$ of nonspecific DNA. Biotherm Taq DNA polymerase was combined with various amounts of double-stranded DNA fragment A: lane 1, control (no DNA fragment added); reactions shown in lanes $2,3,4,5,6$ and 7 contained $0.3,0.6,0.9,1.2,2.4$ and $3.6 \mu \mathrm{g}$ of double-stranded DNA fragment A, respectively. Reaction parameters were as described in Materials and Methods. The positions of the specific amplification product (upper arrow) and of the double-stranded fragment added (lower arrow) are indicated. 
a-g). Double-stranded DNA fragments of different sequences were tested for their ability to enable a successful low copy number target amplification in the presence of a high background of nonspecific DNA (lanes 4-7 and d-g; sequences summarized in Table 1). The presence of the DNA fragments enabled the amplification of the specific target to a similar amount (estimated by comparing visually the fluorescence intensity). This amplification was completely suppressed in the controls (lanes 2 and b) and also if + and - strands of the different DNA fragments were added as single strands to separate reactions (shown for the + strand of DNA fragment A in lanes 3 and c). Despite the presence of double-stranded fragments, complete suppression was observed when Vent or $P$ wo DNA polymerase were used, and only minor amounts of specific product were obtained with Tth DNA polymerase (data not shown).

The amount of double-stranded DNA fragments required for a maximal yield of specific product has been determined (Figure 4). Here, $0.6 \mu \mathrm{g}$ of fragment A per unit of Biotherm Taq DNA polymerase were found to be optimal (lane 3), while the addition of $>1.2 \mu \mathrm{g}$ resulted in complete inhibition of enzyme activity (lanes 6 and 7).

Taq DNA polymerase bound to high-affinity oligonucleotide ligands (aptamers) has been reported to retain its full activity at temperatures above $40^{\circ} \mathrm{C}$. As the activity of Taq DNA polymerase is reported to be already more than 15 -fold higher at $55^{\circ} \mathrm{C}$ compared to that at $37^{\circ} \mathrm{C}(6)$, the extension of misprimed oligonucleotides at temperatures above $40^{\circ} \mathrm{C}$ during the initial heating of the reaction mixture is expected to occur more frequently and therefore be more detrimental to reaction specificity.

Figure 5A shows how a maximum of specificity is obtained by a precisely calibrated adaptation of the melting temperature of the double-stranded fragments to a given cycle profile. We compared the ability of double-stranded DNA fragments of different melting temperatures to suppress the amplification of undesirable sequences when
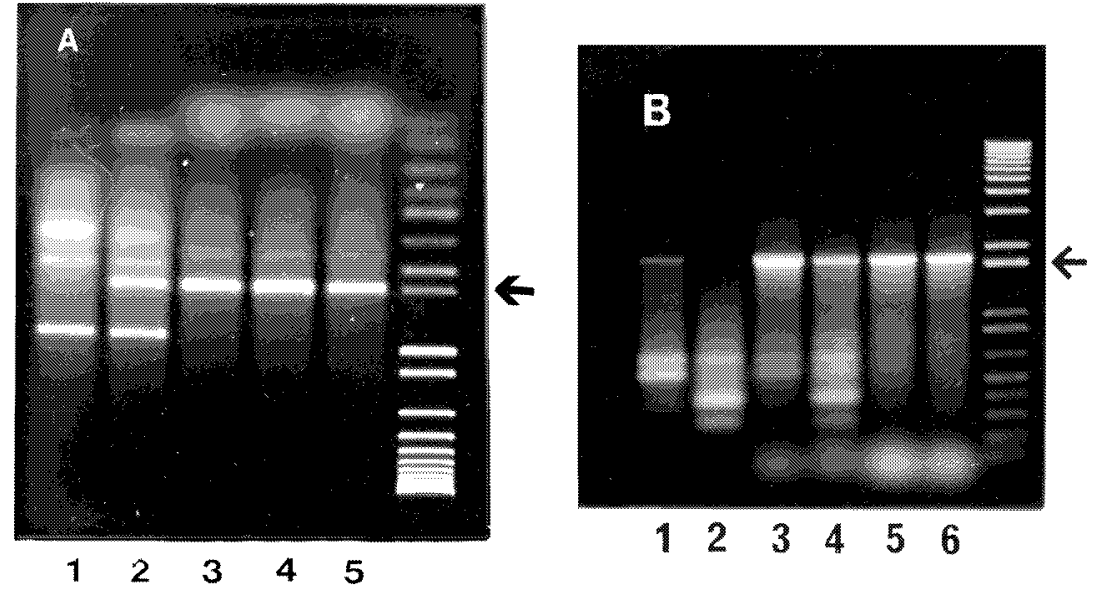

$\begin{array}{llllll}1 & 2 & 3 & 4 & 5 & 6\end{array}$

Figure 5. Influence of melting temperatures of double-stranded DNA fragments on reaction specificity. In panel A, the high melting temperature primer pair 3 and Biotherm Taq DNA polymerase were used to amplify a $1 \mathrm{~kb}$ target sequence starting with approximately 10 copies of $\lambda$ DNA in a background of $2 \mu \mathrm{g}$ of nonspecific DNA. The cycling conditions were as follows: 2 min at $93^{\circ} \mathrm{C}$, followed by 45 cycles consisting of $50 \mathrm{~s}$ at $66^{\circ} \mathrm{C}, 1.5 \mathrm{~min}$ at $78^{\circ} \mathrm{C}$ and $1 \mathrm{~min}$ at $93^{\circ} \mathrm{C}$; and 1 final extension cycle of $50 \mathrm{~s}$ at $66^{\circ} \mathrm{C}$ and $3 \mathrm{~min}$ at $78^{\circ} \mathrm{C}$. Lane 1, control, no double-stranded DNA fragment added; lanes $2,3,4$ and 5 contained $0.6 \mu \mathrm{g}$ of double-stranded DNA fragments A, E, F and G, respectively. See Table 1 for the sequences of primers and DNA fragments. In Panel B, a $1.7 \mathrm{~kb}$ target was amplified using primer pair 2 and Biotherm Taq DNA polymerase (10 copies of $\lambda$ DNA, $2 \mu \mathrm{g}$ of nonspecific DNA, for cycling conditions see Materials and Methods). Reactions shown in lanes 2, 4 and 6 were allowed to cool to room temperature for $5 \mathrm{~min}$ after the first denaturation step. Lanes 1 and 2, controls, without double-stranded DNA fragment; lanes 3 and 4, containing double-stranded DNA fragment A; lanes 5 and 6, containing double-stranded DNA fragment E. 


\section{Short Technical Reports}

using high melting primers (primer pair 3, Table 1) and two-step PCR using $78^{\circ} \mathrm{C}$ as the annealing-extension temperature. The results indicate that effective hot-start conditions are obtained if the reaction mixtures contain doublestranded DNA fragments with measured melting temperature values between $60^{\circ} \mathrm{C}$ and $70^{\circ} \mathrm{C}$ (fragments E-G in lanes 3-5). The addition of DNA fragment $\mathrm{A}\left(\mathrm{T}_{\mathrm{m}}\right.$ meas. $\left.55.5^{\circ} \mathrm{C}\right) \mathrm{re}-$ sulted in amplification of the target sequence together with several nonspecific sequences (lane 2), while in the control (no DNA fragment added), no specific product was obtained (lane 1).

The usefulness of specificity-enhanced hot-start PCR is not restricted to specifically amplifying low copy number targets in a high background of nonspecific DNA. If the target number was raised to $2 \times 10^{4}$ molecules and the background was reduced by $50 \%$, thus resembling a more usual PCR application, specificity and product yield were still significantly enhanced compared to the controls (not shown).
Generally, for achieving maximal specificity in PCR, it is conceivable to use the highest possible stringency at the highest permissible temperature. Nevertheless, the melting temperature values of primers (as calculated by the usual software programs) are always lower than those that provide maximum specificity (5). However the addition of double-stranded fragments of the appropriate length enables a PCR to be run at annealing temperatures of low stringency without any adverse effects on reaction specificity.

The full-time protection against mispriming events is shown in Figure 5B. Even by temporary removal of PCR probes from the machine, thereby allowing them to cool down to room temperature, no unfavorable effects on reaction specificity and product yield were noticed (lanes 5 and 6). In contrast to the optimal protection obtained by the addition of double-stranded DNA fragment $E$, the presence of its truncated version (fragment $\mathrm{A}$ ) allowed some nonspecific amplification accompanied by reduced product yield (lanes 3 and 4). Mainly, nonspecific products are seen in the controls (lanes 1 and 2). This prevention of extending misannealed primers can be explained by the thermal reversibility of the inhibition.

Although it is conceivable that the double-stranded DNA fragments may cause false priming themselves in certain instances, we never observed such a phenomenon of interference. Under PCR conditions, renaturing of complementary fragments is most likely favored over annealing to template sequences of only partial complementarity.

In summary, the variant of hot-start PCR presented offers the possibility to select the temperature range at which $T a q$ and Tfl DNA polymerases are inhibited and thus prevented from extending misannealed primers, a protection that persists during the entire amplification. The high degree of specificity obtained should render this procedure useful in a variety of applications such as the amplification of viral sequences out of tissue samples.

\section{REFERENCES}

1.Birch, D.E., L. Kolmodin, W.J. Laird, N. McKinney, J. Wong, K.K.Y. Young, G.A.
Zangenberg and M.A. Zoccoli. 1996. Simplified hot start PCR. Nature 381:445-446.

2.Chou, Q., M. Russel, D.E. Birch, J. Raymond and W. Bloch. 1992. Prevention of prePCR mis-priming and primer dimerization improves low-copy-number amplifications. Nucleic Acids Res. 20:1717-1723.

3.Dang, C. and S.D. Jayasena. 1996. DNA inhibitors of Taq DNA polymerase facilitate detection of low copy number targets by PCR. J. Mol. Biol. 264:268-278.

4.D'Aquila, R.T., L.J. Bechtel, J.A. Videler, J.J. Eron, P. Gorcyca and J.C. Kaplan. 1991. Maximizing sensitivity and specificity of PCR by pre-amplification heating. Nucleic Acids Res. 19:3749.

5.Gelfand, D.H. and M.A. Innis. 1999. Optimization of PCR: Primer Design Factors, p.18-19. In M.A. Innis, D.H. Gelfand and J.J. Sninsky (Eds.), PCR Applications Protocols for Functional Genomics. Academic Press, San Diego, CA.

6.Gelfand, D.H. and T.J. White. 1990. Thermostable DNA Polymerases, p.130-131. In M.A. Innis, D.H. Gelfand, J.J. Sninsky and T.J. White (Eds.), PCR Protocols A Guide to Methods and Applications. Academic Press, San Diego, CA.

7.Horton, R.M., B.L. Hobbe and B.M. ConteTronconi. 1994. Ampligrease: "hot start" PCR using petroleum jelly. BioTechniques 16:42-43.

8.Kellogg, D.E., I. Rabalkin, S. Chen, N. Mukhamedova, T. Vlasik, P.D. Siebert and A. Chenchik. 1994. TaqStart antibody ${ }^{\mathrm{TM}}$ : "hot start" PCR facilitated by a neutralizing monoclonal antibody directed against Taq DNA polymerase. BioTechniques. 16:1134-1137.

9.Lin, Y. and S.D. Jayasena. 1997. Inhibition of multiple thermostable DNA polymerases by a heterodimeric aptamer. J. Mol. Biol. 271:100-111.

We wish to thank Dr. Verena Kainz for her critical review of the manuscript. Address correspondence to Dr. Peter Kainz, Institute of Chemistry and Biochemistry, University of Salzburg, Hellbrunnerstrasse 34, A-5020, Salzburg, Austria. Internet: peter.kainz@mh.sbg.ac.at

Received 3 February 1999; accepted 14 October 1999.

\section{Peter Kainz, Angela Schmiedlechner and Hans Bernd Strack Institute of Chemistry and Biochemistry University of Salzburg Salzburg, Austria}

